\title{
RACISM: AFRICAN AMERICANS' EXPERIENCES AS VICTIMS OF SLAVERY AND SEGREGATION AS IMPLEMENTED BY THE POLICIES OF WHITE SUPREMACY
}

Fred Bedell ${ }^{*}{ }^{凶}$

${ }^{* 1}$ ED.D Fountain Hills, AZ, USA

DOI: https://doi.org/10.29121/granthaalayah.v9.i3.2021.3804

Article Type: Research Article

Article Citation: Fred Bedell. (2021). RACISM: AFRICAN AMERICANS' EXPERIENCES AS

VICTIMS OF SLAVERY AND SEGREGATION AS IMPLEMENTED BY THE POLICIES OF WHITE SUPREMACY. International Journal of Research -GRANTHAALAYAH, 9(3), 309-320.

https://doi.org/10.29121/granthaa layah.v9.i3.2021.3804

Received Date: 15 March 2021

Accepted Date: 31 March 2021

Keywords:

Dominant

Subordinate

Slavery

Segregation

Racism

White Supremacy

Oppression

\begin{abstract}
This essay will be divided into three parts - Slavery, Segregation, and Past and Recent Events that will document the impact on the social, political, and economic fabric of marginalized communities. It will focus on the social construct theory of domination and subordination and the caste system that subjugated African Americans under the guise of white supremacy.
\end{abstract}

\section{INTRODUCTION}

I began my career in teaching, and I was fortunate to have a role in integrating the schools in the Westchester Public School District in New York state. The Brown vs. Board of Education of Topeka was a landmark decision of the U.S. Supreme Court in which the court ruled the U.S. state-established racial segregation in public schools was unconstitutional (Wikipedia 5/7/54).

My career in education and youth services allowed me to work in agencies whose mission was dedicated to civil rights and equal opportunity for youth and adults.

In my retirement I decided to share my experiences via writing essays and books. This essay is (I consider it a trilogy) a retrospective of the African American experience culminating in my work and research, namely, my book, "Historical Events as a Basis for Income Inequality and Social Injustice" (2019). My current essay, "The Impact of the 
Racism: African Americans' Experiences as Victims of Slavery and Segregation as Implemented by The Policies of White Supremacy

Coronavirus (Covid-19) Pandemic Exposes the Inequalities and Inequities on Marginalized Communities" (July 2020)

The Covid-19 Pandemic exposed the racial injustice and inequalities that still exist in communities of color. Coupled with the police brutality perpetrated on minorities, it has awakened America to examine the soul of the country as it pertains to race relations. These narrative attempts document the struggle of African Americans to pursue life, liberty, and happiness.

In research and writing articles, the writer searches for facts to reaffirm his or her beliefs. We take parts of records or documents and develop an argument to defend our position. It is within this context this essay is written.

The United States in its infancy was a slave society, where the privileged class got its labor from indentured servants and African slaves to support the economy, mainly in the South.

\section{PART ONE - SLAVERY (1619 - 1865)}

Slavery in the United States was the legal institution of human chattel enslavement, primarily of Native Americans and Africans that existed in the U.S. from the beginning of the nation until the passage of the Thirteenth Amendment in 1865 (Wikipedia).

Slavery was the primary catalyst of the civil war which fostered secession from the union. It was led by southern political leaders in opposition to attempts of northern political forces to block the expansion of slavery into western territories.

The slave trade provided political power, social standing, wealth, and privilege to European Nation states and New World colonies and individuals. The South became dependent on slave labor for its economic survival.

In the colonies, status began to be defined by race and class, and whether by custom, case law, or statute, freedom was limited to maintain the enterprise of slavery to ensure power (Wikipedia).

Khalil Mohammad in his book "The Contradiction of Blackness" states that the founders of the Constitution were enriched by capital, slaves, and land. The Constitution was for all intents and purposes designed to protect the further acquisition of property for the privileged class (words did not match the reality that all men are created equal). Nonprivileged class people, e.g., dark-skinned people, women, and children were not included in the document.

\subsection{THE ORIGIN OF THE WORD "RACE"}

Professor Will Collins of Devry University culled information from the writings of Frederickson, G.M., Summer, A., and Slipton, Nancy, regarding the invention of race in our society. He notes that the invention of race was a folk idea, not scientific. It was institutionalized (circa 1700) as a set of culturally created attitudes about human group differences.

Race and its ideology about human differences arose out of the concept of African slavery. The first people to be enslaved by the English were the Irish and Indians. Oddly enough, African servants and bonded indentured white servants were treated the same way. They often joined together as in the case of the Bacon Revolution in 1676 to oppose the strict and oppressive laws of the colonial government. The Irish and the Indians did not make good slaves, and freed whites demanded land privileges that were refused by the upper-class colonial government.

African labor provided a buffer against the poor whites. Until the 18th century (1700), the image of Africans was generally positive. They were farmers and cattle breeders. They had industry, arts and crafts, government, and commerce.

In addition, Africans had immunities to Old World diseases. They were better laborers, but they had nowhere to escape to once they were transplanted into the New World. The colonists came to believe they were dependent on Africans for their survival.

The institution of slavery was fully established for Africans and their descendants.

To rationalize the slave trade, Africans were classified as heathens, and it was the Christian duty to save their souls.

As a consequence of anti-slavery feelings, pro-slavery forces found it necessary to develop new arguments for defending the institution focusing on the notion of natural inferiority. 
Race had been a classificatory term like "type" or "kind" which was ambiguous but crystallized into a reference for African Americans.

The physical features of different groups became the marker or symbol of their status and justified their positions within the social system.

Race ideology proclaimed that the social, spiritual, moral, and intercultural inequality of different groups was their physical traits, natural and innate, inherited, and unalterable.

Separateness and inequality were what race was all about. The attributes as the inferior race statutes came to be applied to free Blacks as well as slaves (Collins 2020).

\subsection{HUMANS AND PROPERTY}

Slaves were both humans and property, so the question became, "How do you treat a human being as both a human and a piece of property?" More importantly, "What should take precedence - the human rights of the slave or the property rights of the owner?"

American laws cleared that dilemma up as the property rights were more sacred than the people, said Chief Justice Roger B. Taney in the famous Dred Scott Case of 1857, as the slaves were not intended by the framers of the Constitution to be accorded citizenship rights.

In order to change people, you must minimize those qualities that make them human (see Appendix - "All Lives Matter" flyer). In other words, you must dehumanize them.

In the many decades since the Civil War, societies made great strides to keep the Negro in his place. Public policies, e.g., "Jim Crow" and the customs and practices of millions of Americans expressed the racist worldview through the twentieth century.

Race ideology was a mechanism justifying what had already been established as unequal. Social grouping was a mechanism justifying what had already been established as unequal social grouping. It was, from its inception and is today, about who should have access to privilege, power, status, and wealth and who should not. This ideology can be explained as a social construct of dominance and subordination between the "haves" and the "have nots" rooted in white supremacy as a social structure (Collins 2020).

\subsection{SOCIAL CONSTRUCT}

Racism is defined as the belief that different races possess distinct characteristics, abilities, or qualities, especially so as to distinguish them as inferior or superior to one another (Oxford Dictionary, Wikipedia).

Underneath racism is white supremacy. The white people (especially white men, because they dominated white society) were the pinnacle of the evolution of the human species and therefore were racially superior to all other races. This philosophy was behind the exploitation of Africans for free slave labor and the economic gain for white businessmen during the era of the slave (Collins 2020).

Layla F. Saad defines white supremacy in her book, "Me and White Supremacy" as follows: "White supremacy is a racial ideology that is based upon the belief that white people are superior in many ways to people of other races, and therefore white people should be dominant over all races.

White supremacy is not just an attitude or a way of thinking. It also extends to how systems and institutions are structured to uphold white dominance."

The theory of a social construct is the idea that race, class, and gender don't really mean anything, because societies give them meaning. Unlike a mountain, the existence of race, gender, or class requires that people collectively agree, that it does not exist.

The definition of social construct in simple terms is a way of looking at a social phenomenon (in the case of race) of creating and institutionalizing a tradition by mankind- dominance and subordination. This ideology is a set of behaviors and rituals evolving in the submission of one person or a group. Subordinate persons are called "submissive", and the group holding the power is called "dominant" (Bedell 2014). 
Racism: African Americans' Experiences as Victims of Slavery and Segregation as Implemented by The Policies of White Supremacy

\section{PART TWO - SEGREGATION (1865 - 1954)}

\subsection{THE CASTE SYSTEM}

A caste system is defined as a class structure that is determined by birth. Loosely, it means that in some societies, if your parents are poor, you are going to be poor too. Same goes for the rich - a division of society based on differences of wealth, inherited rank, privilege, profession, occupation, or race (Wikipedia).

Dr. Martin Luther King visited India with his wife. He wanted to see and learn about the country that fought for freedom from British rule. During his tour, he visited a local high school, and the principal introduced him to the students as an untouchable (the lowest caste in the Indian system). King was floored, as he never expected that word to be applied to him. He did not see the connection. Then he began to think about the reality of the lives of the people he was fighting for - 20 million, consigned to the lowest ranks in America for centuries, still smothering in airtight cages of poverty, quarantined in isolated ghettos - exiled in their own land. Author Isabelle Wilkerson tells the story of Dr. King's experience in an article written in the New York Times Magazine section titled, "America's Enduring Racial Caste System."

Before the modern era, one of the earliest Americans to take up the caste was the antebellum abolitionist and U.S. Senator Charles Sumner as he fought against segregation in the North. "The separation of children in the public schools of Boston on account of race," he wrote, "is in the nature of caste and on this account a violation of equality. Caste makes distinctions among creatures where God has none. (Wilkerson 2020)."

\subsection{RECONSTRUCTION - (1865-1877)}

Following the Civil War (1861-1865) and the Emancipation Proclamation, the country entered the era of Reconstruction. Northerners came to the south as missionaries, teachers, businessmen, and politicians. Hostile whites began referring to the politicians as "carpetbaggers." This period was called the Reconstruction period. Cruel and severe black code laws were adopted to control or reimpose the old social structure. Southern legislatures passed laws that restricted the civil rights of the emancipated former slaves. Black codes were adopted by midwestern states to regulate or inhibit migration of free African Americans.

Congress passed an act on March 3, 1865, to establish the Bureau of Refugees, Freedmen and Abandoned Lands. The program was administered by the Department of War.

Although Congress responded with legislation that led to the Civil Rights Act of 1866, states kept laws on the books that continued the legacy of the black codes, and therefore second-class citizenship to the newly freed slaves (Lincoln Library System, Howard University).

Vice President Andrew Johnson seceded President Lincoln after his assassination and implemented a plan of Reconstruction that gave the white South a free hand in regulating the transition from slavery to freedom and offered no role to blacks in the politics of the South.

The South reestablished the black code laws in the form of the so-called "Jim Crow" laws. These laws remained on the books for almost a century but were finally abolished with the passage of the Civil Rights Act of 1964 .

\subsection{BLACK CODE LAWS (VAGRANCY LAWS)}

Mississippi law required blacks to have written evidence of employment for the coming year each January. If they left before the end of the contract, they would be forced to forfeit earlier wages and were subject to arrest. In South Carolina, a law prohibited blacks from holding any occupation other than farmer or servant. Some states limited the type of property that blacks could own, if at all. White Supremacist paramilitary organizations, allied with southern democrats, used intimidation, violence, and even committed assassinations in order to repress blacks and prevent them from voting. In addition, they established poll taxes and literary tests for voting eligibility.

In that moment, the slave realized that the land of the free had imposed a caste system not unlike the caste system of India, and that he had lived under that system all his life. (Wilkerson 2020)

Ms. Wilkerson intimates, "Once awakened to the underlying power of caste, we can better see the tool of race for what it is, a mutation of the software that adjusts to the updated needs of the operating system." Social scientists 
often describe racism as the combination of racial bias systems with personal or group power over another person or group with less power, as men have power over women. White people have power over people of color and dominate over the subordinate (social construct).

Caste on the one hand predates the notion of race and has survived the era of formal state-sponsored racism long officially practiced in the mainstream (Wilkerson).

Caste is structure. Caste is ranking. Caste is the boundaries that reinforce the fixed assignments based upon what people look like. Caste is a living, breathing entity, like a corporation that seeks to sustain itself at all costs. Caste is the granting or withholding of respect, status, honor, attention, privilege, resources, benefit of the doubt, and human kindness to someone on the basis of their perceived rank or standing in the hierarchy. It sees as logical as an example - a white 16-year-old serving as a store manager over employees from the subordinate class three times his age.

What is the difference between racism and caste? Caste and race are interwoven in America, and it is hard to separate the two, according to Ms. Wilkerson.

Any action or structure that seeks to limit, hold back, or put someone in a defense ranking seeks to keep someone in their place by elevating or denigrating that person in their perceived category, and can be seen as casteism. Casteism is the investment in keeping the hierarchy, as it is in order to maintain your own ranking as advantage or privilege or to elevate yourself above others to keep others beneath you, particularly in marginalized communities (Wilkerson 2020). So, in this context, you have the basis for segregation.

\section{PART III - PAST AND RECENT EVENTS IMPACTING THE LIVES OF AFRICAN AMERICANS}

The events described below document the activities to diminish the status and lives of African Americans.

Wilmington, North Carolina, Insurrection of 1898

The Wilmington, North Carolina, Insurrection of 1898, also known as the Wilmington Massacres of 1898, occurred in Wilmington, North Carolina. White Supremacists were working to reverse the advances made by former slaves and their offspring. By the 1890s, Wilmington was North Carolina's largest city and a shining example of a mixed-race community. It was a bustling port city with a burgeoning African American middle class and a progressive government, referenced David Zucchino in his book, "Wilmington Lies." Wilmington was a community that the government of both republican and populist included black aldermen, police officers, and magistrates. There were successful black- owned businesses and an African American newspaper, "The Record." It was evident that a segment of the white population was averse to this prosperity of former slaves.

In North Carolina, democrats were plotting to take back the state legislature in November by the "ballot or bullet" or both and then started a race riot to overthrow the present multi-racial government with intimidation and violence. The democrats suppressed the black vote to win control of the state on November 8, 1898. Two days later, more than 2,000 heavily armed redshirts swarmed through the city, torching The Record newspaper, terrorizing the black population, and shot sixty black men dead in the streets. The rioters forced city officials to resign and replaced them with mob leaders.

This insurrection is a rare instance of a violent overthrow of an elected government in the U.S. It halted the gains made by blacks and restored racism as the official government policy, cementing white rule for another half century (Zucchino).

The events of November 10 in the 1898 Massacre were the result of a long-range campaign strategy by Democratic Party leaders to regain political control of Wilmington, the state's largest city at the time. ("The Lost History of an American Coup D’État," written by Adrianne LaFrance and Vann R. Newkirk in The Atlantic magazine, 8/12/17).

\subsection{TULSA, OKLAHOMA MASSACRE (5-31-6-1-1921)}

The race massacre in Tulsa, Oklahoma, took place on May 31st and June 1st, 1921, when mobs of white residents, many of them deputized and given weapons by city officials, attacked black residents and businesses of the Greenwood Community District in Tulsa, Oklahoma (Wikipedia).

In 1921 Oklahoma had a racially, socially, and politically tense atmosphere. World War I had ended in 1918. With the return of male servicemen and the American Civil War still a living memory even though it had ended in 
1865, civil rights for disenfranchised people were lacking, and the "Ku Klux Klan" was resurgent and exacerbated an already tense environment.

Tulsa, as a booming oil city, supported a large number of efficient, educated, and professional African Americans. This combination of factors played a large part in the rising tensions which were to culminate into a race riot.

Greenwood was a district in Tulsa organized in 1906 that became so prosperous that it became known as the "Black Wall Street." Blacks had created their own businesses and services, including several grocers, two movie theaters, night clubs, two newspapers, and numerous churches. Black professionals included doctors, dentists, lawyers, and clergy that served their peers. Needless to say, Greenwood prospered and participated in the oil boom.

The riot began over the Memorial Day weekend after 19-year-old Dick Rowland, a black shoe shiner, was accused of assaulting Sarah Page, a 17-year-old white elevator operator. He was arrested and taken into custody (later exonerated); however, rumors and talk spread that he was going to be lynched. A mob of a hundred white men were confronted by a large group of armed black men, which ensued into a riot that led to white rioters rampaging and devastating black neighborhoods. The attack by white rioters was not only carried out on the ground but also by private aircraft, which destroyed more than 35 square blocks of the district at that time, the wealthiest black community in the United States.

Three days after the massacre, President Warren G. Harding condemned the riots as the worst uprising since the American Civil War. A number of reparation commissions were formed and recommended restitution to the victims - but restitution was never delivered (Wikipedia).

Juneteenth (June 19) represents the anniversary of the Tulsa massacre, which has been called the worst incident of racial violence in American history. Oddly enough, President Trump scheduled a campaign rally that day in 2020 but was advised to reschedule it - which he did. Juneteenth became a state holiday in Texas, and a number of states subsequently followed suit. Efforts are being made to make it a national holiday.

\subsection{PROTESTS}

Protesters took to the streets to raise their voices against oppression, racial injustice, and income inequality. A list of these protests is noted as follows:

\subsection{OCCUPY WALL STREET}

Occupy Wall Street was a protest movement against economic equality/racial injustice that began in Zuccotti Park located in New York City's Wall Street financial district in September 2011. It gave rise to the wider "Occupy" movement in the United States and other countries (Wikipedia).

\subsection{RODNEY KING}

Rodney King was an American construction worker turned writer after surviving an act of police brutality by the Los Angeles police on March 3, 1991. King was beaten by LAPD officers after a high-speed chase during his arrest for drunk driving on Route I-20. A civilian, George Holiday, filmed the incident which showed an unarmed King on the ground being beaten after evading arrest. The incident was covered by news media around the world and caused a public furor.

It was stated by the Los Angeles police chief that the police used excessive force taking him into custody. In the review, it was found that the officers struck him with batons between fifty-three and fifty-six times. No charges were filed against Mr. King.

The four officers were eventually tried on charges of use of excessive force. Of those, three were acquitted, and the jury failed to reach a verdict on one charge for the fourth.

The verdict sparked a riot lasting for six days by outraged racial minorities over long- standing social issues. 


\subsection{ERIC GARNER}

New York Police Department Officers (NYPD) approached Garner on July 17, 2014, on suspicion of selling single cigarettes from packs without tax stamps. Garner told the police that he was tired of being harassed and that he was not selling cigarettes.

The officers attempted to arrest Garner who had pulled away, and the police officer placed his arms around Garner's neck and wrestled him to the ground. With multiple

officers pinning him down, Garner repeated the words, "I can't breathe." 11 times while lying face down on the sidewalk.

The medical examiner rules Garner's death a homicide, as the cause of death was a choke hold; asthma, heart disease, and obesity were cited as contributing factors.

The Richmond County grand jury decided not to indict the officer. This decision stirred public outcry and rallies, with charges of police brutality made by the protesters.

\subsection{MICHAEL BROWN JR.}

On August 9, 2014, Michael Brown Jr., an 18-year-old black man was fatally shot by 28- year-old Darren Wilson, a white Ferguson, Missouri, police officer. Ferguson is a suburb of St. Louis, Missouri. Brown was accompanied by his 22-year-old friend Dorian Johnson. Wilson said that an altercation ensued when Brown attacked Wilson in the police vehicle for control of Wilson's gun until it was fired. Johnson claimed that Wilson initiated a confrontation by grabbing Brown by the neck through the car window, threatening him and then shooting at him. At this point, both Wilson and Johnson stated that Brown and Johnson fled, with Wilson pursuing Brown shortly thereafter. Wilson stated that Brown stopped and charged him after a short pursuit. According to Johnson, Wilson shot Brown multiple times.

In the entire altercation, Wilson fired a total of twelve bullets, including twice during the struggle in the car. Brown was struck six times, all in the front of his body.

This event ignited unrest in Ferguson, and protests ensued. A subsequent FBI investigation found that there was no evidence that Brown had his hands up in surrender or said, "Don't shoot." However, protesters claimed he had done so. A subsequent grand jury decided not to indict the police officer, Wilson. The U.S. Department of Justice concluded that Wilson shot Brown in self-defense (Wikipedia).

\subsection{GEORGE FLOYD}

George Perry Floyd was a black American man killed on May 25, 2020, during an arrest after allegedly passing a counterfeit $\$ 20$ bill in Minneapolis, Minnesota. A white police officer, Derek Chavin, after apprehending him, knelt on Floyd's neck (see All Lives Matter flyer in the appendix) for nearly eight minutes which proved to be fatal. After his death, protests against police violence toward black people quickly spread across the United States and internationally.

The official autopsy report classified Floyd's death as a homicide attributed to cardiopulmonary arrest caused by subdual and restraint.

Protests began in Minneapolis the day after his death and developed in over 400 cities through all 50 states and internationally. The case is presently in litigation.

The protests highlighted the Black Lives Matter movement. Black Lives Matter (BLM) is an organized movement in the United States advocating for non-violent civil disobedience in protest against incidents of police brutality against African American people.

What makes these protests more powerful than previous ones is the joining of multi- ethnic groups, especially white people, both men and women (Wikipedia).

\subsection{MONUMENTS}

The removal of Confederate monuments is driven by the belief that the monuments glorify white supremacy and memorialize a treasonous government whose founding principal was the perpetuation and expansion of slavery. 
Racism: African Americans' Experiences as Victims of Slavery and Segregation as Implemented by The Policies of White Supremacy

The vast majority of these Confederate monuments were built during the era of "Jim Crow" laws (1877 - 1964) (Wikipedia).

These are statutes of Colonial and Civil War generals and presidents who were slaveholders, so the question is, "What statues should stay, and which ones should be removed?"

So, a standard should be established. I believe Jon Meacham, historian and writer has suggested a standard that addresses this dilemma, which is, "Did the individuals contribute to the creation of the country or its destruction?"

The Confederate generals and politicians advocated the secession of the Confederate States from the union. This was treasonous, but they wanted to establish a Confederate slave nation that encompassed the Caribbean Islands as well and therefore should not be venerated in public spaces. The statues belong in museums that tell the story of the history of the nation.

\subsection{THE WASHINGTON REDSKINS - NATIONAL FOOTBALL TEAM}

George Floyd's death while in police custody in Minneapolis spurred protests, riots, and a social movement in the United States and internationally. It led to statues being toppled and removed, and Confederate flags were banned from Nascar tracks and taken down from southern state capitals.

The coronavirus pandemic has left the country with time to think, resulting in louder and louder demands for change.

It eventually led to more pressure being applied to the Washington's franchise to change its name. Multiple companies, including sponsors of the team and the NFL, spoke out in support of social justice reforms.

Nike released another statement that read in part, "Systemic racism and the events that have unfolded across America the past few weeks serve as an urgent reminder of the continued change needed in our society."

The team's name "Redskins" is "racist, insulting, and offensive to our Native Americans and is finally being removed from the franchise." It reminds me of a former governor of Arizona, Evan Mecham, who opposed having Martin Luther King's birthday designated as a state holiday. Pressure from black football players who refused to play in the football Super Bowl scheduled for Arizona encouraged business leaders and politicians to convince the governor that having King's birthday as a state holiday was in the state's best economic interest.

Lessons are learned when economic considerations are in play; the hearts and minds of the populace will follow. And more importantly, Peter Beinart, American columnist stated, "Oppression produces violence, and justice and equality produce peace."

And last but not least, the election of Barack Obama to the presidency of the United States. . .

\subsection{BARACK OBAMA}

The election of Barack Obama to the presidency of the United States caused great consternation within the Republican Party. So much so that after the election, the Republican Party had a meeting to determine how to deal with a Black president. It is noted that Mitch McConnell, the Senate Majority Leader stated that, "The Republican Party will be the party of "no" to Obama's legislative initiatives, and we will do everything in our power to make him a one-term president."

Let's look at three examples (out of many) that President Obama was subjected to in his tenure in office:

1) During President Obama's State of the Union Address, a southern congressman cried out, "You lie!" This outburst was one of a kind, as it never happened to any previous sitting president.

2) Jan Brewer, former governor of Arizona, ran across the tarmac and poked a finger in his face as if to scold him as he prepared to board his airplane.

3) The current Republican president, Donald Trump, while he was a candidate for the office, led a crusade known as the "Birther Movement" to question President Obama's birthplace when it was commonly known that he was born in Hawaii. He later recanted the accusation when he had a conference with President Obama in the transition interview after his election.

On the Charlie Rose TV Program on August 9, 2016, Michael Morell, former deputy director of the CIA, spoke to issues facing America and indicated that he was struck by the discourse pertaining to the racial attitudes that were 
prevalent in the Republican presidential campaign given by candidate Donald Trump (2016). Mr. Morell was asked by an Australian magazine to give an analysis of the politics in the U.S., which he did. One of the three cited examples that interested me most was the one that appealed to a segment of the population (white) espoused by Candidate Trump. Mr. Morell stated, "There is a segment of the population who fears the "Browning of America;" who fear the number of minorities and their influence on the political process as manifested by the election of Barack Obama to the presidency - a direct threat to the ideology of white supremacy."

Michael Edison Hayden (Newsweek) reported on March 27, 2018, that Sheriff Joe Arpaio claimed he proved that President Obama's birth certificate was fake and would resume the debunked "Birther Movement" if elected to the Senate.

Ex-Sheriff Joe Arpaio was convicted of criminal contempt. He garnered nationwide attention for his crackdown on illegal immigration and at that time was told he could not detain immigrants simply because they lacked legal status. But for 18 months his deputies carried on the practice. The ruling carried a possible maximum sentence of six months in jail and a monetary fine for the 85-year-old Arpaio. He was subsequently pardoned by President Trump.

And lastly, the current Coronavirus Pandemic ...

\subsection{CORONAVIRUS (COVID-19) PANDEMIC (2020)}

The Coronavirus attack on the world in general and the United States in particular, has forced a lockdown strategy and strict hygiene guidelines. People who are able to work from home are luckier than people who do not have that option and fill the unemployment ranks. Various businesses have closed and put their workers on furlough or on unemployment.

This Pandemic has shed a light on how vulnerable we are as a planet and as a nation to the forces of nature. It has also placed a spotlight on the fragility of our institutions that were established for the health and safety of our country. Unfortunately, when we thought that we had the virus under control, it resurged in 35 states, mainly due to the incoherent messaging coming from the White House leadership and the populace's indifference to following the Centers for Disease Control (CDC) hygienic guidelines.

The impact of the Coronavirus Pandemic is reflecting the racial and socioeconomic disparities of the cities where it is spreading and crippling the health systems that are struggling to contain it. Unfortunately, communities of color have been hit the hardest.

Research shows:

- African Americans are more likely to have severe underlying health conditions, including heart disease, diabetes, hypertension, and some cancers that make the virus infections more severe.

- Lower-income areas which tend to have larger non-white populations have less access to health care services. The quality of care is also often worse than what wealthier parts of the counties receive.

- Low-income workers are not likely to have health insurance. They're also less likely to be able to work from home and are therefore more likely to keep going to work and putting themselves more at risk.

- Substandard housing, multiple families living together, and homelessness all facilitate the virus spread.

- Lehigh University's Sirry Alang, who studies health disparities and inequities, says, "There is a need for people in these communities to shape a response for justice and equity and form alliances and organizations to communicate the message to the political establishments."

I would submit that this is the message that all the protests are giving. So, what do we conclude?

\section{CONCLUSIONS}

The current Coronavirus Pandemic, coupled with the tragic murder of George Floyd by a police officer in Minneapolis, Minnesota, has ignited protests in the United States and around the world, voicing concerns about police brutality, social injustices, income inequality, and the inequities of racism's impact on communities of color.

This essay highlights racism and the African American experience as victims of slavery and segregation as implemented by the policies and practices of the ideology of white supremacy. 
Racism: African Americans' Experiences as Victims of Slavery and Segregation as Implemented by The Policies of White Supremacy

We as a country are fighting for the soul of America as stated in the Constitution that, "All men and women are created equal," and that "Black Lives Matter," as all lives matter. There are present movements that are addressing these issues, particularly the protests that have drawn multi-ethnic groups, giving strength to the messages. A participation by the majority ethnic group provides a legitimacy and urgency for change in social and political discourse.

Books addressing the issues of racism, social injustice, and income inequality are prominent on the New York Times best seller lists.

Churches are hosting "Racial Equity Challenge" seminars that aim to help participants deepen their understanding of racism and examine their own biases.

State legislatures are passing sweeping police accountability bills such as the state of Oregon. The following is a summary of the legislation: Transparent policing and use of force reform; outlaw the use of respiratory restriction restraints; duty to report and intervene; transparency of police discipline records; protecting freedom of speech and assembly from excessive force, and discipline guidelines and arbitration decisions.

Recently, the taking down of Confederate monuments and flags from state capitals in the south is a significant step in racial sensitivity. In addition, changing the name of the Washington Redskins National Football League franchise, which is offensive to the Native American population, is a major step forward in race relations. Change can be accomplished when economic issues are prevalent (their hearts and minds will follow).

"To label is to divide," is an observation made by a friend of mine who is currently a university professor. He recounts his experiences as an employee of a Fortune 500 corporation and states, "Historically, we (African Americans) have been called many names. His ancestors have birth records labeling them Indian, Mulatto, and Negro. More recently, Black, Afro-American, African American, and people of color have been added to the lexicon, omitting derogatory descriptions. He refers to a label of Plans for Progress (PFP) that hire then advance to Equal Opportunity Employees (EOE) These became buzz words to describe efforts and results in minority hiring. In effect, if you were not white you often were viewed as a product of "Affirmative Action" and not because you were qualified for a particular position. Taking this concept of "labeling" to divide is a method of polarization - divide and conquer. We use it in describing, Black and white, red states and blue states, liberal and conservative, elites, etc. Is this the current administration's campaign strategy for reelection? It is a rhetorical question. You decide.

What is needed is investment in marginalized communities. I call it an infrastructure safety net.

George Lakoff defines the mission of government as follows: "Politics is about working for and representing people and the concerns of citizens' everyday lives. The mission of government is to protect and empower all equally through the use of the public (commons), defined as resources for the betterment of life provided for all." This concept has made for a civilized and humane private lifestyle and prosperous private enterprise.

Dr. Martin Luther King advocated for economic and social rights during his campaign for the poor and civil rights for marginalized communities, which is, I believe, the investment that is needed today. It is noted as follows:

- The right of every employable citizen to a minimum job - the right of every citizen to a minimum income

- The right to a decent house and a free choice of neighborhood

- The right to participate in the decision-making process

- The right to full benefits of modern science and health care

To say the least, we are a long way from achieving the aspirations of Dr. King, but now is the time to start. So, let us conclude with an anonymous source who analyzed the Constitution:

\subsection{THE CONSTITUTION - FIRST AMENDMENT}

"We the people of the United States, in order to form a more perfect union, establish justice, ensure domestic tranquility, provide for the common defense, promote the general welfare, and secure the blessing of liberty to ourselves and our prosperity, do ordain and establish this Constitution for the United States of America."

The analysis is noted as follows:

1) "Establish Justice" - If a segment of the population is subjected to police brutality and unfair incarceration, it would be your constitutional duty to oppose that system and fix it to establish justice. 
2) "Domestic Tranquility" - To ensure it, you listen to people's complaints and their right to peaceful assembly, you avoid confrontation and violence, and you petition for a redress of grievances.

3) "Promote the General Welfare and Provide for the Common Defense" - It means we protect each other (Wear masks. My mask is to protect you, and your mask is to protect me.). It is your constitutional duty to wear a mask and to protect your community.

if there were a systemic issue that prevents a segment of the population from prospering, it would be your constitutional duty to oppose it.

4) "Secure the Blessing of Liberty" - Do not elect persons of ill will who refer to journalists as the enemy because of criticism. Freedom of the press is embedded in the Constitution, because it is important to the functioning of a represented democracy, and there are groups who oppose the founding document of this country. We all should be concerned about our responsibilities as citizens of a democracy. As my friend Karl says, "That's my story, and I'm sticking to it."

\section{ALL LIVES MATTER}

\section{The Constitution states, "We hold these truths to be self evident that all men (and women) are created equal."}

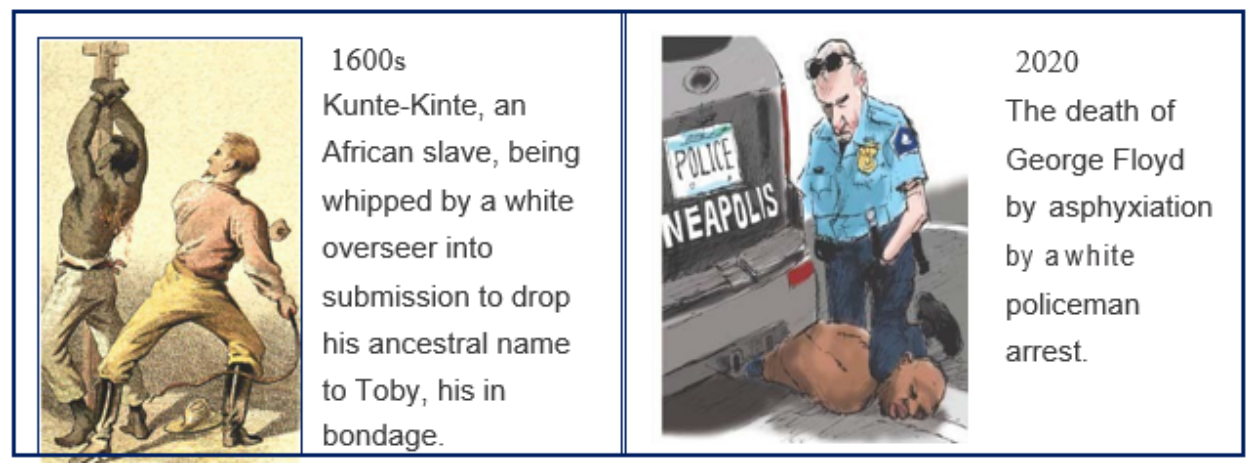

A little African boy (enslaved) asked the overseer why he was whipping the man and the overseer retorted, "He was born free and had to be subjugated, you were born into slavery so you don't know the difference."

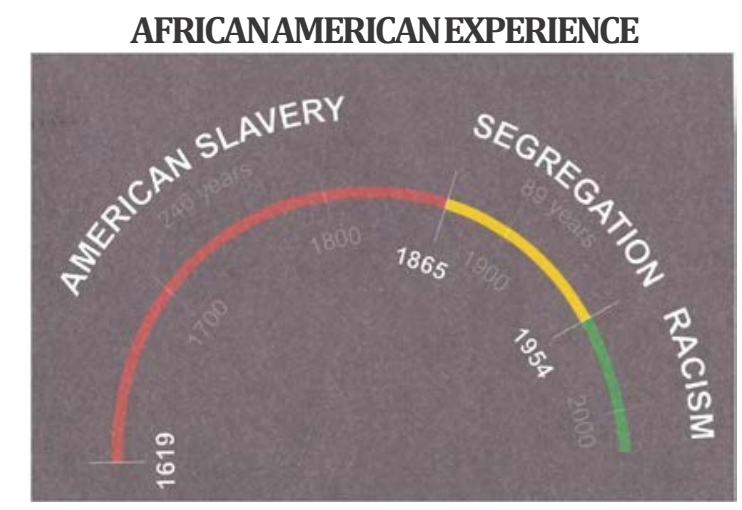

The framework for inequality is inherent in the cultural/social context of domination and subordination (social construct) as depicted in the illustrations above and rooted in White Supremacy.

We are fighting for the soul of America in this "BLACK LIVES MATTER" as the creedembedded in the Constitution of the United States.

Fred Bedell-2020

(picture of a white overseer beating a slave from the TV series, "Roots," based on Alex Haley's book) 
Racism: African Americans' Experiences as Victims of Slavery and Segregation as Implemented by The Policies of White Supremacy

\section{SOURCES OF FUNDING}

This research received no specific grant from any funding agency in the public, commercial, or not-for-profit sectors.

\section{CONFLICT OF INTEREST}

The author have declared that no competing interests exist.

\section{ACKNOWLEDGMENT}

None.

\section{REFERENCES}

[1] Alang, Sirry (2019). Lehigh University.

[2] Bedell, F. (2019). Historical Events as a Basis for Income Equality and Social Inequality. (2020). The Impact of the Coronavirus (Covid-19 Pandemic Exposes the Inequalities and Inequities of Marginalized Communities.

[3] Beinart, P. (2020). American Columnist, TV Program, Fareed Zakaria Interview.

[4] Fredrickson, G.M. (1984). (as referenced in the text).

[5] LaFrance, A. (2017). The Last History of an American Coup D’État, The Atlantic.

[6] Lakoff, G. (2014). The Little Blue Book.

[7] Lincoln Library (2014). Howard University.

[8] Meacham, J. (2020). Historian, TV Program, Christiane Amanpour Interview.

[9] Mohammad, K. (2014). The Contradiction of Blackness.

[10] Morell, M. (2016). TV Program, Charlie Rose Interview.

[11] Saad, L. (2020). Me and White Supremacy.

[12] Summer, A. (1973). (as referenced in text)

[13] Slepton, N. (1982). (as referenced in text)

[14] Wilkerson, I. (2020). America's Enduring Racial Caste System, NY Times Magazine.

[15] Wikipedia (as referenced in text).

[16] Zucchino, D. (2020). Wilmington Lies. 